\title{
Oxythermal window drastically constraints the survival and development of European sturgeon early life phases
}

\author{
Nicolas Delage ${ }^{1,2,3} \cdot$ Blandine Couturier $^{1}$ - Philippe Jatteau ${ }^{1} \cdot$ Thibaut Larcher $^{4,5}$ - Mireille Ledevin ${ }^{4,5}$. \\ Hélicia Goubin ${ }^{4,5}$ • Jérôme Cachot ${ }^{2} \cdot$ Eric Rochard $^{1}$ (C)
}

Received: 26 July 2018 / Accepted: 17 December 2018

(C) Springer-Verlag GmbH Germany, part of Springer Nature 2019

\begin{abstract}
European sturgeon Acipenser sturio is an anadromous fish species being classified "critically endangered" with only one remaining population in the Gironde-Garonne-Dordogne basin (France). In the global warming context, this paper aims to determine the sensitivity of $A$. sturio early life phases to temperature and oxygen saturation. Embryos were experimentally exposed to a combination of temperature $\left(12\right.$ to $30{ }^{\circ} \mathrm{C}$ ) and oxygen $\left(30\right.$ to $90 \% \mathrm{O}_{2}$ saturation) conditions. Lethal and sublethal effects were evaluated using embryonic mortality, hatching success, malformation rate, yolk sac resorption, tissue development and swimming speed. Embryonic survival peaked at $20{ }^{\circ} \mathrm{C}$ and no survival was recorded at $30{ }^{\circ} \mathrm{C}$ regardless of the associated oxygen saturation. No hatching occurred at $50 \% \mathrm{O}_{2}$ sat or below regardless of temperature. Malformation frequency appeared to be minimum at $20{ }^{\circ} \mathrm{C}$ and $90 \% \mathrm{O}_{2}$ sat. Swimming speed peaked at $16^{\circ} \mathrm{C}$. The temperature optimum of early life phases of A. sturio was determined to be close to $20{ }^{\circ} \mathrm{C}$. Its upper tolerance limit is between 26 and $30{ }^{\circ} \mathrm{C}$ and its lower tolerance limit is below $12{ }^{\circ} \mathrm{C}$. Oxygen depletion induces sublethal effects at $70 \% \mathrm{O}_{2}$ sat and lethal effects at $50 \% \mathrm{O}_{2}$ sat. Within the spawning period in the Gironde-Garonne-Dordogne basin, we identified yearly favourable oxythermal windows. Consequences of climate change would depend of the phenological adaptation of the species for its spawning period.
\end{abstract}

Keywords Sturgeon $\cdot$ Temperature $\cdot$ Oxygen $\cdot$ Behaviour $\cdot$ Development $\cdot$ Mortality $\cdot$ Global warming

\section{Introduction}

From the beginning of the twentieth century, the European sturgeon Acipenser sturio populations have been in sharp

Responsible editor: Philippe Garrigues

Eric Rochard

eric.rochard@irstea.fr

1 IRSTEA EABX, Aquatic Ecosystems and Global Changes Research Unit, 50 Avenue de Verdun, 33612 Cestas, France

2 University of Bordeaux, UMR CNRS EPOC 5805, Allée Geoffroy Saint-Hilaire - CS 50023, 33615 Pessac Cedex, France

3 Present address: Agence Française de la Biodiversité, Pôle Gest'Aqua, 65 rue de St Brieuc, 35042 Rennes Cedex, France

4 INRA,UMR 703 APEX, Oniris La Chantrerie, Nantes, France

5 LUNAM Université, École nationale vétérinaire, agro-alimentaire et de l'alimentation Nantes-atlantique (Oniris), Nantes, France decline due to a combination of anthropogenic pressures, notably overfishing and habitat destruction (Rochard et al. 1990).

Nowadays, the only remaining population of European sturgeon inhabits the Gironde-Garonne-Dordogne (GGD) basin in southwest France (Lassalle et al. 2010; Williot and Castelnaud 2011). This species is strictly protected and listed in many conventions and European directives (Rochard 2011) and National action plans were set up in France and Germany following a European action plan (Rosenthal et al. 2007). The last evidence of natural reproduction in the GGD basin was observed in 1994 (Rochard et al. 2001). A captive brood stock was established at the Saint Seurin-sur-l'Isle research station from adults and juveniles captured in the wild, and individuals from assisted reproduction. Since 1995, over 1.7 million juveniles and larvae have been produced and subsequently released into the Garonne and Dordogne rivers to support the wild population. Depending on their life period, European sturgeons are encountered across the Gironde Estuary, the Bay of Biscay and the North Sea (Rochard et al. 1997; 
Lepage and Rochard 2011). It is generally expected that upon reaching maturity, they will return to their native catchment to breed and spawn (Acolas et al. 2011).

We have studied the physical characteristics of potential spawning grounds for A. sturio in the GGD basin (Jego et al. 2002), but as in most of the European basins, the environmental conditions have changed during recent decades. Especially, the summer average surface water temperature have increased by $2.9^{\circ} \mathrm{C}$ in Garonne between 1978 and 2005 (Larnier et al. 2010), and hypoxic events have been recently recorded in the Garonne tidal river part (Lanoux et al. 2013). These trends are expected to continue in the future (Caballero et al. 2007; Rabalais et al. 2010; IPCC 2013).

According to Magnin (1962), the potential spawning period of A. sturio in the GGD basin extended from May to June. At this period of the year, the temperature of the water column near potential spawning zones ranged from 10.2 to $28.2{ }^{\circ} \mathrm{C}$ and oxygen saturation ranged from 44.5 to $111.4 \% \mathrm{O}_{2}$ sat (Table 1). During the spawning season, $\mathrm{PH}$ at the spawning grounds varies rapidly within a wide range depending on the variation of the river flow from tributaries with different physicochemical characteristics. From our records (2014-2016), minimum, median and maximum values were respectively 5.5, 7.6 and 8.7.

It is well documented that elevated temperatures can induce ontogenesis impairment in fish (Johnston et al. 2009; Kieffer et al. 2011) leading to developmental defects (Lo et al. 2011). It can also impair physiological performances (Gisbert et al. 2002; Hassell et al. 2008b), behaviour (Dalla Via et al. 1998) and even survival (Hassell et al. 2008b). Hypoxia can also affect fish survival and fitness at several developmental phases (Clark et al. 2013; Kappenman et al. 2013). These adverse effects may include developmental abnormalities and reduced hatching success (Hassell et al. 2008a; Lo et al. 2011), changes in space utilisation (Abe and Sakamoto 2011), reduced antipredator behaviour efficiency (Lefrançois and Domenici 2006; Domenici et al. 2007) and induction of DNA damage (Mustafa et al. 2011).

Early life stages of European sturgeon could experience such fluctuations in temperature and dissolved oxygen during their utilisation of the GGD catchment. A preliminary study has shown that for A. sturio, the embryo-larval phase is more sensitive to high temperatures than 3-month-old juveniles (Delage et al. 2014). We observed a drastic decrease in hatching rate for embryos reared at $26^{\circ} \mathrm{C}$ compared to individuals exposed to $20^{\circ} \mathrm{C}$. From an ecological point of view, determining thermal tolerance (upper and lower temperature thresholds) is useful in identifying the distribution of a given species and predicting its possibility of local thermal adaptation (Pörtner 2001; Elliott and Elliott 2010). There is still a lack of knowledge about the combined effects of high temperatures and low levels of dissolved oxygen in the context of global warming.

Metabolism evaluation and bioenergetic analysis provide a unique insight into individual status under physiological stress (Fry 1971). At the embryo-larval stage, respirometric analyses give an opportunity to simultaneously evaluate the cost of development and organogenesis (Gisbert et al. 2002; Mueller et al. 2011). Aerobic metabolism is also closely related to behavioural performances such as antipredator and swimming behaviour (Killen et al. 2015). For example, maximum speed, acceleration and behavioural consistency increase under optimal environmental conditions (Claireaux and Lefrançois 2007). On the other hand, biotic or abiotic stress can impair the relationship between physiological traits and associated behaviour (Killen et al. 2013).

From numerous works, it appears that performances of individual are supported by aerobic scope, defining thermal windows (Pörtner 2001; Clark et al. 2013). Whatever the real shape of the relationship (Clark et al. 2013), we observe a decrease in performance the further we are from the optimum temperature. The width of this thermal window depends on species and is generally narrower for embryos and larvae than for juveniles (Pörtner and Farrell 2008). From the oxygen- and capacity-limited thermal tolerance (OCLTT) hypothesis, the optimal temperature corresponds to the maximum aerobic scope (Pörtner and Farrell 2008; Clark et al. 2013).

As we work on embryos and larvae, most of the precautions to be taken to identify a sound $\mathrm{M}_{\mathrm{O} 2}$ cannot be met (e.g. using the same individuals for the measures in the different conditions; acclimate them during several days before the
Table 1 Temperature and oxygen saturation reported in the GGD basin. Data were collected during the spawning season (May-June) from four locations close to potential spawning grounds, two in Dordogne river
(Libourne and Tuilières) and two in Garonne river (Portets and Golfech). Temperature data were collected from 1993 to 2011 and oxygen saturation data were collected from 2004 to 2011

\begin{tabular}{lllllll}
\hline & & Minimum & First quartile & Median & Third quartile & Maximum \\
\hline Oxygen saturation $(\%)$ & Libourne & 62.02 & 88.12 & 93.73 & 99.17 & 110.03 \\
& Portets & 44.51 & 75.95 & 91.13 & 95.86 & 111.38 \\
Temperature $\left({ }^{\circ} \mathrm{C}\right)$ & Tuilieres & 10.18 & 15.30 & 17.27 & 20.12 & 22.19 \\
& Libourne & 11.96 & 16.98 & 19.93 & 20.61 & 27.48 \\
& Golfech & 11.33 & 15.90 & 20.45 & 22.04 & 27.78 \\
\hline
\end{tabular}


exposure...) (Clark et al. 2013). For this reason, we propose not to focus only on $\mathrm{M}_{\mathrm{O} 2}$ but to identify the optimal temperature and dissolved oxygen conditions through a combination of biological (survival, hatching rate), metabolic (oxygen consumption), behavioural (swimming speed) and developmental (kinetic and abnormalities) indicators. Using these indicators, we propose a combined integrated criterion to determine a compromise optimal temperature and oxygen ranges for the development and survival of early phases of European sturgeon. This criterion would help us to better estimate the suitability of the GGD basin for the development of young European sturgeons.

According to Pörtner (2001; Pörtner and Farrell 2008), when assessing the environmental sustainability of an organism, it is essential to define thresholds for the maximum capacity range in aerobiosis (called critical temperatures) and the tolerance range (within the limits of performance called pejus temperatures).

\section{Materials and methods}

\section{Embryo collection and conditions of exposure}

Exposure conditions were designed to replicate the range of temperature and oxygen concentrations found in the lower part of the GGD (see Table 1). Temperatures tested ranged from 12 to $30^{\circ} \mathrm{C}\left(12{ }^{\circ} \mathrm{C}, 16{ }^{\circ} \mathrm{C}, 20^{\circ} \mathrm{C}, 23{ }^{\circ} \mathrm{C}, 26^{\circ} \mathrm{C}, 30{ }^{\circ} \mathrm{C}\right)$. Dissolved oxygen saturation tested ranged from 30 to $90 \% \mathrm{O}_{2}$ sat $(30,50$, 70 and $90 \% \mathrm{O}_{2}$ sat). Dechlorinated tap water was used during the experiment with a $20 \%$ volume renewal per day.

Embryos and larvae were monitored using the purposebuilt exposure system for European sturgeon described in Delage et al. (2014). In each experiment, two parental origins were used in order to prevent putative parental effects. After fertilisation (Delage et al. 2014), the water temperature was gradually modified $\left(1{ }^{\circ} \mathrm{C}\right.$ per hour) from $18{ }^{\circ} \mathrm{C}$ to reach the targeted exposure temperature within 2 to $12 \mathrm{~h}$. Around 150 embryos per replicate were exposed to exposure conditions until yolk sac resorption (between 9 and 21 days depending on incubation temperature). Once the exposure temperature was reached, hypoxia exposure gradually started to reach the targeted $\mathrm{O}_{2}$ level. Oxygen depletion lasted $48 \mathrm{~h}$. The oxygen level was then increased back to $90 \% \mathrm{O}_{2}$ sat. Temperature and oxygen saturation were checked and recorded every 2 min over the course of the experiment using a parameter control and recorder unit (SOFREL, S550; LACROIX, Vern sur Seiche, France). A 12-h darkness and 12-h light cycle was used. The $\mathrm{pH}$ was maintained around a median value of 7.76 $(\min =5.83, \max =8.18)$.

\section{Embryo-larval assay}

Mean embryo viability was evaluated for each condition and each genetic cross. Dead embryos and larvae were counted and removed twice a day (morning and evening) in order to assess mortality. Mortality during the first day of the experiment was not taken into account since it may be due to handling and unfertilized oocytes. Hatching rate (HR) in each incubator was recorded every $2 \mathrm{~h}$ from the first hatching event and up to $12 \mathrm{~h}$ after the last one.

Gross malformations were recorded in eleutheroembryos (yolk-sac larvae at 2 days post hatch) using binocular microscopy (Olympus ZX12). Three types of malformation were distinguished: oedema, skeletal axis deformations and heart malformations.

In addition, 39 yolk-sac larvae, from all conditions, were fixed in $4 \%$ formalin for at least $24 \mathrm{~h}$ for a histopathological evaluation and 39 others for assessment of chondrous tissue development.

For histopathological evaluation, samples were dehydrated in graded ethanol solutions and embedded in paraffin. The principles of step sectioning have already been published for zebrafish (Spitsbergen et al. 2000). For the present study, serial sagittal step sections were cut from the left side of the larvae. Four-step sections from each larva were mounted on glass slides, one from eye anterior chamber level, one from eye posterior chamber level, one just medial to the eye and one at the midline. Sections were routinely stained with haematoxylin-eosin-saffron (HES). All lesions were recorded by a skilled pathologist. The area of the yolk sac was measured on the midline section using a digital camera combined with a dedicated software (Nikon Imaging Software, Nikon, Badhoevedorp, The Netherlands).

Chondrous tissue development was assessed using the alcian blue-alizarin red double staining technique (Darias et al. 2010). Briefly, whole larval carcasses were first immersed in Alcian blue (Sigma, Saint Quentin Fallavier, France) for cartilage staining for $30 \mathrm{~min}$, before neutralisation for $3 \mathrm{~min}$ with a solution of $1 \% \mathrm{KOH}$ in ethanol. After rehydration, 1 volume $3 \% \mathrm{H} 2 \mathrm{O} 2$ and 9 volumes $1 \% \mathrm{KOH}$ were used to bleach larvae for $25 \mathrm{~min}$. After clearing in $30 \%$ sodium borate with $1 \mathrm{~g}$ trypsin (Sigma) for $20 \mathrm{~h}$, calcification centres were stained with alizarin red (Sigma) for $1 \mathrm{~h}$. The larvae were dehydrated and preserved in $100 \%$ glycerol. Gross abnormalities were recorded and individual chondral development was evaluated using a cumulative score (e.g. Shields et al. 1997; Kovacs et al. 2002) reflecting alcian blue-positive tissues in jaw, skull, vertebral axis, pectoral and dorsal fins.

Semi-quantitative evaluation of tissue development for post hatch larvae was performed for skin, gill, liver and yolk sac. For skin, individual score was determined upon chromophorous cell presentation as follows: $0=$ cellular body, $1=$ cytoplasmic processes, 2 = epidermal pigmentation. For gill, individual score was determined as follows: $0=$ no lamellae, $1=$ sprouting, 2 = mature lamellae. For liver, individual score was determined upon sinusoid capillary presentation as follows: $0=$ blood capillary dilatation (also known as peliosis), $1=$ 
mature vascularisation. For yolk sac, individual score was determined upon epithelium presentation as follows: $0=$ pavimentous epithelium, 1 = cubic epithelium, 2 = cubic to columnar epithelium with epithelial folds. An individual composite index of tissue development expressed in percentage was then calculated as the ratio between the sum of skin, gill, liver and yolk sac scores and the maximal total score.

Larval spontaneous swimming behaviour was evaluated using Ethovision ${ }^{\circledR 9}$ software (Noldus). Individual larvae were placed in Petri dishes of $10 \mathrm{~cm}$ diameter filled with rearing water on an infrared light floor. Experiments were performed at rearing temperature. An infrared camera (Ikegami ${ }^{\circledR}$ ) was placed above the equipment. Ten individuals per replicate were tested simultaneously. The room light was switched off $1 \mathrm{~h}$ before the beginning of the test to allow larvae to acclimatise. Video recording lasted $20 \mathrm{~min}$ in darkness and mean speed was measured every $30 \mathrm{~s}$.

Aerobic metabolism was measured using routine metabolic rate (RMR). The respirometric chamber (Qubit system, G113 cylindrical chamber, Canada) containing system is composed with an enclosed chamber filled with 10 larvae. The respirometric chamber can be filled with water through two valves using a peristaltic pump (Qubit system, PP300, Canada). Eight respirometric chambers operated simultaneously throughout the experiment. Oxygen saturation in each system was recorded using fibre-optic needle-type sensor (Qubit system, Canada). A water current, around $2 \mathrm{~cm} / \mathrm{s}$, was establish in the respirometer chambers to enforce larvae to swim. In closed circuit condition, there is no water renewal, enabling to measure the oxygen consumption by organisms. In an open circuit condition, water is renewed to reestablish initial oxygen conditions. Individuals were acclimatised during $1 \mathrm{~h}$ in darkness and at rearing temperature before their oxygen consumption was measured (Gisbert et al. 2002; Mueller et al. 2011). Oxygen consumption was recorded during five periods of $5 \mathrm{~min}$ in closed circuit condition (Mueller et al. 2011). Oxygen saturation never decreases under $80 \% \mathrm{O}_{2}$ sat during the recording period. At the end of the test, fish were removed and a last recording was performed to evaluate micro-organism oxygen consumption in each chamber. Each individual fish was weighed and measured at the end of the experiment.

\section{Statistical analysis}

Statistical analysis was performed using the $\mathrm{R}$ software $^{1}$ ( $\mathrm{R}$ foundation for Statistical Computing, Vienna, Austria). Replicated conditions were considered as independent experiments. Data normality was checked using the Shapiro-Wilk test and equality of variance was verified using the Bartlett

\footnotetext{
${ }^{1} \mathrm{R}$ Development Core Team (2014). R: A language and environment for statistical computing. R Foundation for Statistical Computing, Vienna, Austria. ISBN 3-900051-07-0, URL: http://www.R-project.org.
}

test. In the case of a normal distribution of data and equality of variance, an analysis of variance was performed (ANOVA) followed by a Tukey post hoc test. When one of these criteria was not fulfilled, a non-parametric Kruskal-Wallis test was performed, followed by a Wilcoxon test for the embryolarval experiment. Putative effects of parental origins were tested using the same method.

\section{Results}

\section{Acute effects}

An ANOVA test showed statistical differences in embryonic survival between temperature conditions $(p$ value $<0.01)$ and between oxygen conditions ( $p$ value $<0.01$ ) allowing to establish two groups, one exposed to 50 and $30 \% \mathrm{O}_{2}$ sat with very low survival $(0-5 \%)$ and the other one exposed to 70 and $90 \% \mathrm{O}_{2}$ sat with higher survival (mean 24.5\%) (Fig. 1). In normoxia, maximum survival rate of embryos was observed at $20{ }^{\circ} \mathrm{C}$, and lethal high temperature was $30^{\circ} \mathrm{C}$. The survival shape is similar at $70 \% \mathrm{O}_{2}$ sat, with a lethal high temperature observed at $26{ }^{\circ} \mathrm{C}$. In our experiment, $30 \%$ and $50 \% \mathrm{O}_{2}$ sat
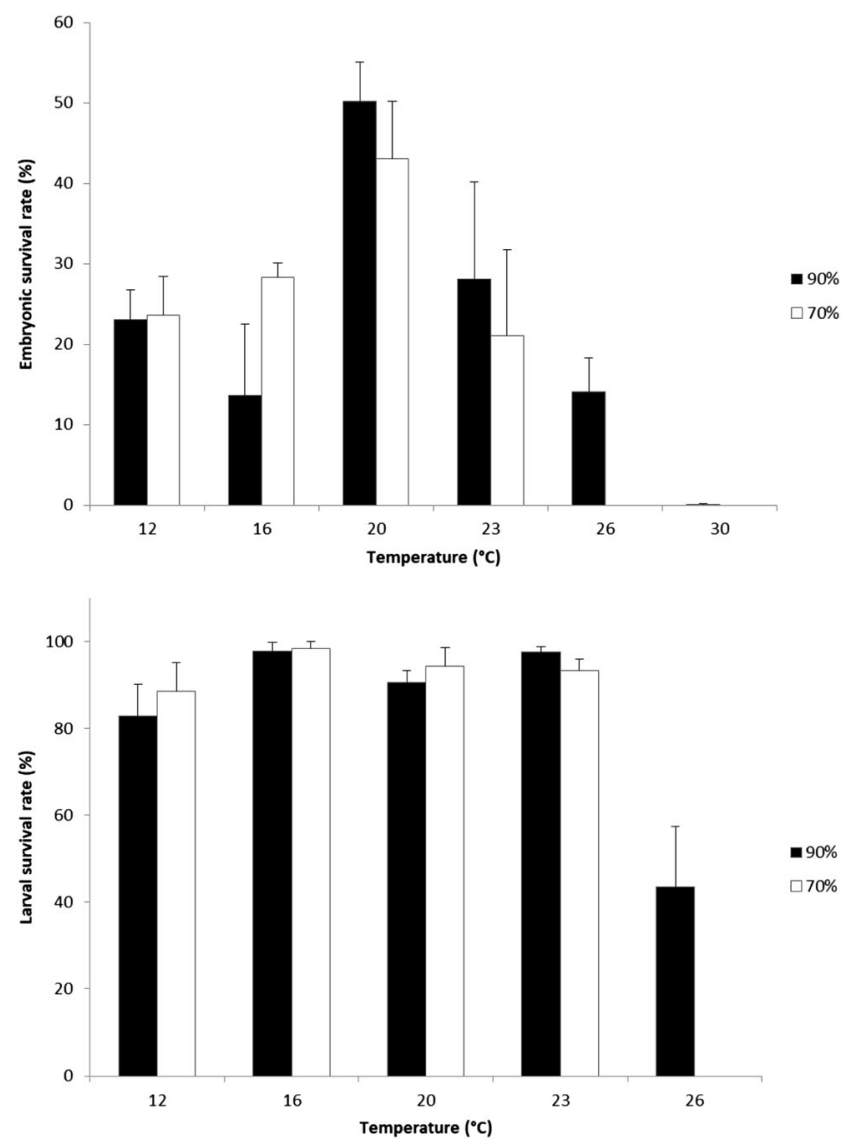

Fig. 1 Embryonic survival (top) and larval survival (bottom) of European sturgeon for the first $48 \mathrm{~h}$ of incubation $(N=102)$ 
were lethal conditions for embryos. We did not detect any statistical difference in the survival rate of larvae exposed at 12 and $23{ }^{\circ} \mathrm{C}$ in both $70 \%$ and $90 \% \mathrm{O}_{2}$ sat. The survival rate was significantly lower at $26^{\circ} \mathrm{C}$ and $90 \% \mathrm{O}_{2}$ sat. We did not observe any embryonic survival at $26^{\circ} \mathrm{C}$ and $70 \% \mathrm{O}_{2}$ sat.

The general shape of the oxythermal relationship is unimodal. In terms of temperature, the best hatching rate (Fig. 2) was observed at $20{ }^{\circ} \mathrm{C}$, while in terms of dissolved oxygen content, the hatching rate peaked at $90 \% \mathrm{O}_{2}$ sat. The best combination $\left(20^{\circ} \mathrm{C}, 90 \% \mathrm{O}_{2}\right.$ sat) led to a hatching rate of $60 \%$. No hatching occurred at $30 \% \mathrm{O}_{2}$ sat whatever the temperature conditions tested and at $30^{\circ} \mathrm{C}$ whatever the oxygen conditions tested. Very few individuals hatched at $50 \% \mathrm{O}_{2}$ sat and $26{ }^{\circ} \mathrm{C}$ (17 over 900$)$. ANOVA showed statistical differences in hatching rates between the different temperature conditions ( $p$ value $<0.01)$ and the different oxygen conditions tested $(p$ value $<0.01)$. No significant difference was observed between 90 and $70 \% \mathrm{O}_{2}$ sat within each temperature condition tested ( $p$ value $>0.05$ ). For all oxygen conditions, the hatching rate was higher at 16,20 and $23^{\circ} \mathrm{C}$ compared to 26 and $30^{\circ} \mathrm{C}$. The hatching rate at $12{ }^{\circ} \mathrm{C}$ (for 90 and $70 \% \mathrm{O}_{2}$ sat) was not statistically different from the other temperature conditions.

\section{Sub-acute effects}

A Kruskal-Wallis test performed on malformation rate data (Fig. 3) showed differences close to significance between conditions ( $p$ value $=0.063$ ). The minimum level of larval deformities $(25.2 \pm 4.3 \%)$ was observed at $20{ }^{\circ} \mathrm{C}$ in normoxia. At lower and higher temperatures, we observed a trend towards an increase in frequency and individual score of deformed larvae (up to $81.8 \%$ at $12{ }^{\circ} \mathrm{C}$ and $83.3 \%$ at $23{ }^{\circ} \mathrm{C}$ ). At $70 \%$ $\mathrm{O}_{2}$ sat conditions (further called suboptimal condition), no significant difference in malformation rate appeared between temperature conditions.

Larval development was first assessed by measuring yolk sac maximal area (yolk-sac larvae at 2 days post hatch) on mid-level sections (Fig. 4). An ANOVA test showed statistical differences between temperature conditions ( $p$ value $<0.01$ ). The largest areas were observed at $12{ }^{\circ} \mathrm{C}$ demonstrating a yolk sac malabsorption at this temperature. No significant difference was observed between 90 and $70 \% \mathrm{O}_{2}$ sat within each temperature condition tested.

Chondrous tissue was observed in 2 days post hatch bleached larvae following alcian blue staining. No calcification was detected after alizarin red staining on the same samples (data not shown). The sequence of chondrous deposition was as follows: jaw, eye-orbit, skull, vertebral axis, pectoral and dorsal/anal fins. At $12{ }^{\circ} \mathrm{C}$, chondrous tissue was only and irregularly detected in jaws, skull and eye-orbits. For higher temperatures, chondrous tissue was more developed and total number of chondral tissue deposition sites was highest at $23{ }^{\circ} \mathrm{C}$ (Fig. 5).

Serial sections ( $4 \mu \mathrm{m}$ thick) of whole larvae were microscopically observed after topographic HES staining. No histopathologic lesion was reported. Tissue development was maximal at $23{ }^{\circ} \mathrm{C}$. In all lower temperatures, cutaneous pigmentation, gill lamellae, hepatic vascularisation and yolk sac epithelium displayed some immature features. No significant difference was observed between 90 and $70 \% \mathrm{O}_{2}$ sat within each temperature condition tested.

Routine metabolic rate (RMR) was used to estimate the aerobic metabolic scope of sturgeon larvae (Fig. 6). An ANOVA test showed statistical differences between oxygen consumption $\left(\mathrm{MO}_{2}\right)$ according to temperature $(p$ value $<0.01)$ and oxygen conditions tested ( $p$ value $<0.01$ ). Maximum RMR were recorded at $20^{\circ} \mathrm{C}$ in normoxia and $16{ }^{\circ} \mathrm{C}$ at $70 \%$ $\mathrm{O}_{2}$ sat. At $12{ }^{\circ} \mathrm{C}, 16^{\circ} \mathrm{C}$ and $23{ }^{\circ} \mathrm{C}$, no significant difference appeared between normoxic and suboptimal conditions. At $20{ }^{\circ} \mathrm{C}, \mathrm{MO}_{2}$ at $70 \% \mathrm{O}_{2}$ sat was significantly lower than $\mathrm{MO}_{2}$ at $90 \% \mathrm{O}_{2}$ sat condition ( $p$ value $<0.01$ ).

Spontaneous swimming speed of larvae was used as a proxy of swimming activity (Fig. 7). Similar patterns were observed in both suboptimal and normoxic conditions. A Kruskal-Wallis test showed significant differences between temperature conditions at $90 \% \mathrm{O}_{2}$ sat $(p$ value $<0.01)$ but
Fig. 2 Hatching rate (\%) of European sturgeon embryos $(N=102)$. No data were collected for 50 and $30 \% \mathrm{O} 2$ sat at 12,16 and $23{ }^{\circ} \mathrm{C}$ and for $70 \% \mathrm{O} 2$ sat at 26 and $30^{\circ} \mathrm{C}$

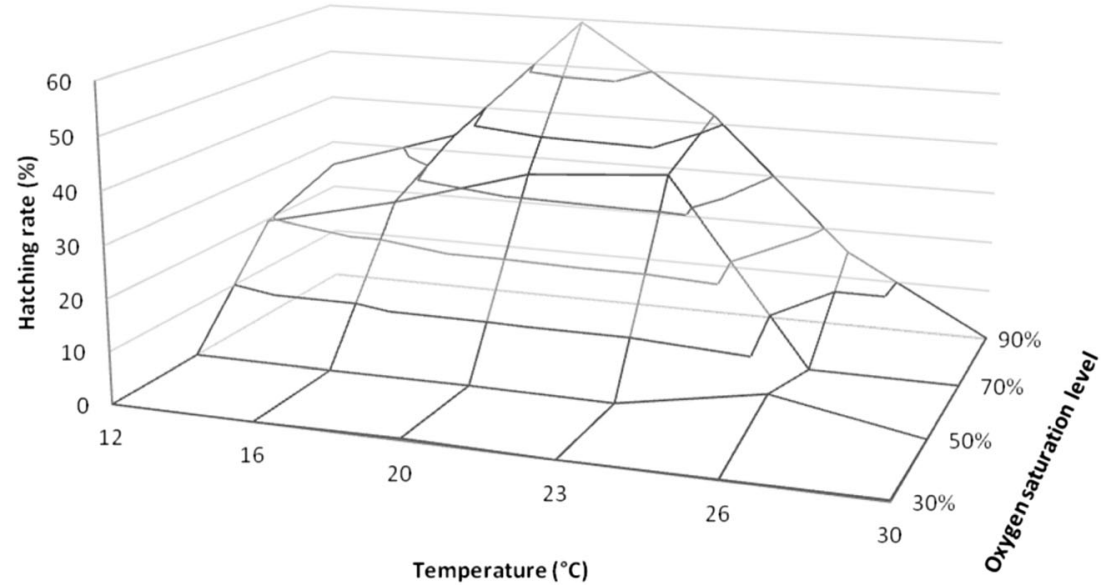




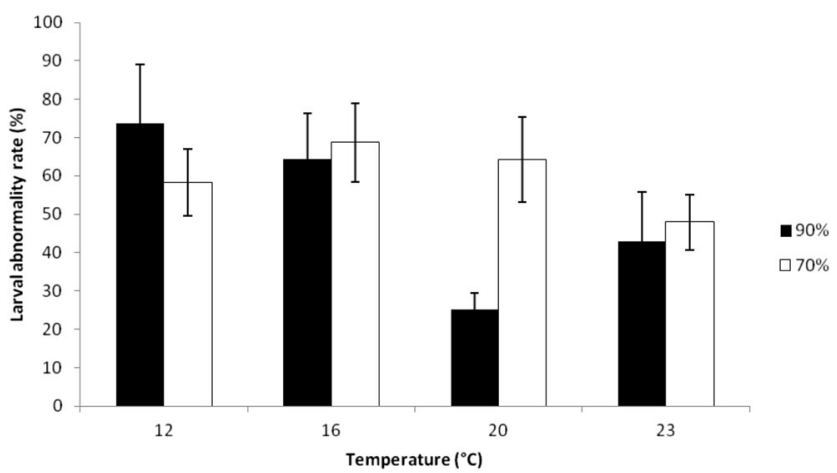

Fig. 3 Malformation rate (mean $\pm \mathrm{SE}$ ) in European sturgeon larvae $(2 \mathrm{dph})$ at $30,50,70$ or $90 \% \mathrm{O} 2$ sat for the first $48 \mathrm{~h}$ of incubation. Because of low survival at this phase, malformation rate could not be evaluated for conditions over $23{ }^{\circ} \mathrm{C}$ and below $70 \% \mathrm{O} 2$ sat. No statistical differences were observed between conditions $(N=47)$

not for $70 \% \mathrm{O}_{2}$ sat conditions. A maximum swimming speed was observed at $16{ }^{\circ} \mathrm{C}$ and $20{ }^{\circ} \mathrm{C}$ at $90 \% \mathrm{O}_{2}$ sat and minimal swimming activity was recorded at $12{ }^{\circ} \mathrm{C}$ and $23{ }^{\circ} \mathrm{C}$. No significant difference appeared when comparing oxygen conditions for a single temperature except at $20{ }^{\circ} \mathrm{C}$ where swimming speed was significantly lower in suboptimal than in normoxic conditions (Wilcoxon test, $p$ value $<0.01)$.

\section{Discussion}

This study brings new results regarding the sensitivity of embryos and larvae of European sturgeon to two environmental drivers, temperature and oxygen. A large panel of approaches (ecology, physiology, ethology, ontology, histology) provided a pattern of responses enabling us to identify the best temperature and oxygen conditions for survival and development of early life phases.

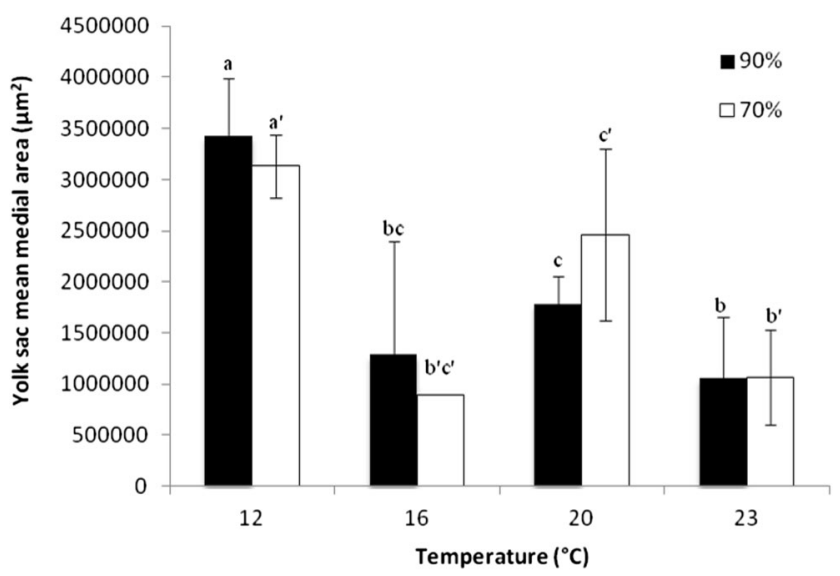

Fig. 4 Yolk sac area $($ mean $\pm \mathrm{SE})$ in 2 dph European sturgeon larvae at 70 or $90 \% \mathrm{O}_{2}$ sat for the first $48 \mathrm{~h}$ of incubation. Statistical differences between temperature conditions are indicated by different letters $(N=31)$

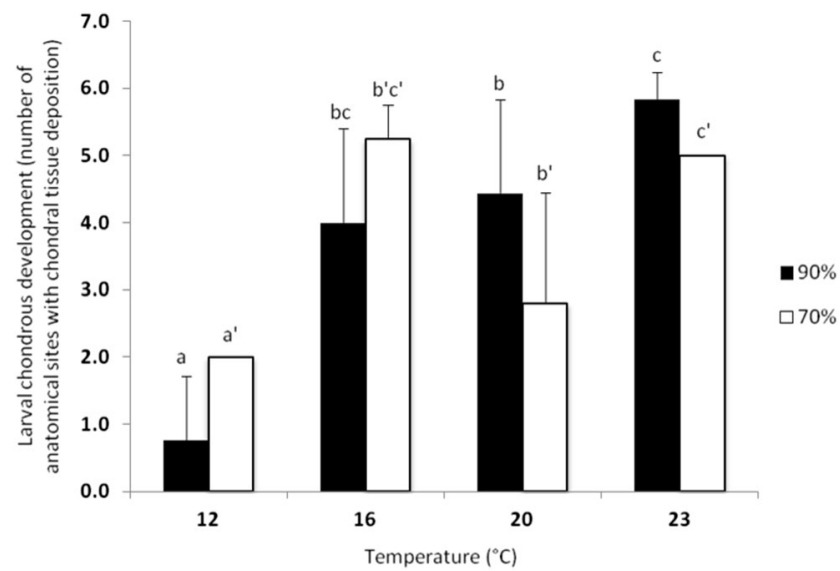

Fig. 5 Number of anatomical sites that displayed chondral tissue deposition (mean $\pm \mathrm{SE}$ ) in $2 \mathrm{dph}$ European sturgeon larvae at 70 or $90 \% \mathrm{O}_{2}$ sat for the first $48 \mathrm{~h}$ of incubation. Statistical differences between temperature conditions as assessed by Kruskal-Wallis test are indicated by different letters $(N=39)$

\section{Effects of temperature on European sturgeon embryos}

In a previous paper (Delage et al. 2014), we demonstrated that embryos and pro-larvae of European sturgeon are very sensitive phases to temperature as for other fish species (Nicholson et al. 2008; Elshout et al. 2013). In this work, we enlarged the range of temperature tested and we considered both lethal and sub-acute effects.

From a same situation at $\mathrm{t} 0$ and $18{ }^{\circ} \mathrm{C}$ and a temperature modification of $1{ }^{\circ} \mathrm{C} / \mathrm{h}$, the target temperatures are reached respectively after $2 \mathrm{~h}\left(16{ }^{\circ} \mathrm{C}\right.$ and $\left.20^{\circ} \mathrm{C}\right), 5 \mathrm{~h}\left(23{ }^{\circ} \mathrm{C}\right), 6 \mathrm{~h}$ $\left(12{ }^{\circ} \mathrm{C}\right), 8 \mathrm{~h}\left(26^{\circ} \mathrm{C}\right)$ and $12 \mathrm{~h}\left(30^{\circ} \mathrm{C}\right)$. We acknowledge that there could be a potential effect, but compared to the duration of the experiment, this delay is limited. Hatching larvae had not the same age but they were at the same phase of development whatever the temperature conditions. For practical reasons, we made most of the observations and tests at 2 days post hatch.

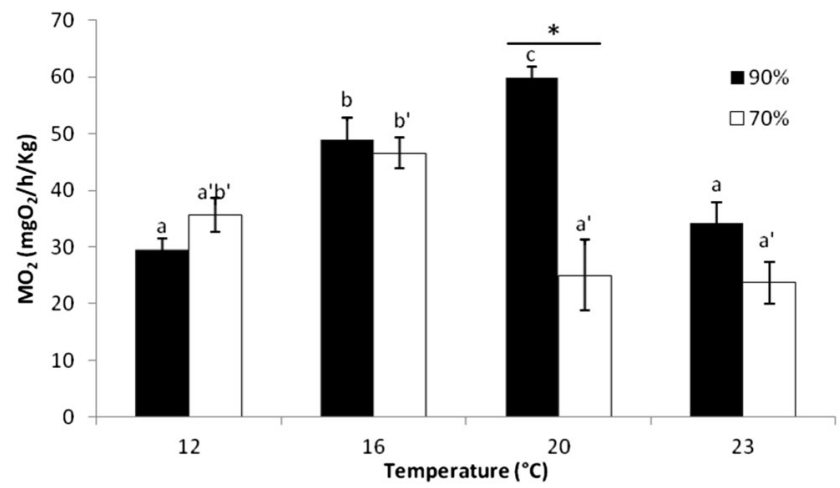

Fig. 6 Evaluation of the routine metabolic rate in 2 dph larvae at 90 and $70 \% \mathrm{O}_{2}$ sat for the first $48 \mathrm{~h}$ of incubation. Because of low survival at this phase, routine metabolic rate could not be evaluated for conditions over $23{ }^{\circ} \mathrm{C}$ and conditions below $70 \% \mathrm{O}_{2}$ sat. Statistical differences between temperature conditions are indicated by different letters. Stars show differences within a single temperature condition $(N=271)$ 


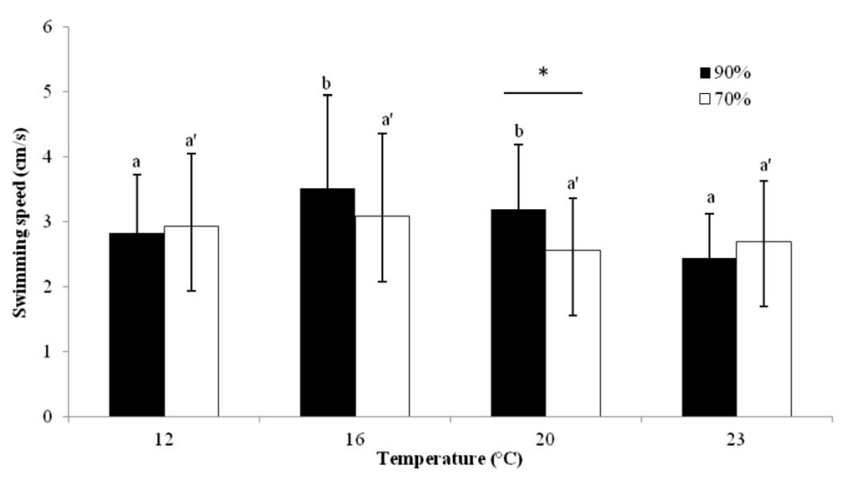

Fig. 7 Two dph European sturgeon larvae swimming speed at 90 and $70 \% \mathrm{O}_{2}$ sat for the first $48 \mathrm{~h}$ of incubation. Because of low survival at this phase, behaviour could not be evaluated for conditions over $23{ }^{\circ} \mathrm{C}$ and conditions below $70 \% \mathrm{O}_{2}$ sat. Statistical differences between temperature conditions are indicated by different letters; stars show differences within a single temperature condition $(N=149)$

And it is possible that at that moment, they were not exactly at the same phase of development. Observed differences resulted partially from the conditions of development before hatching and of the conditions during the 2 days after hatching.

Our results showed that the optimal temperature window of A. sturio embryos and larvae was around $20{ }^{\circ} \mathrm{C}$, which is consistent with previous works on those phases based on empirical knowledge (Williot et al. 2011). The maximum survival, hatching success and routine metabolism capacities were observed at $20^{\circ} \mathrm{C}$. The minimum malformation frequency also occurred at this temperature. Tissue development and yolk sac resorption were maximal at $23{ }^{\circ} \mathrm{C}$. Swimming speed showed a maximum value at $16^{\circ} \mathrm{C}$ and $20^{\circ} \mathrm{C}$.

In normoxia, at $30^{\circ} \mathrm{C}$, there was no embryo survival, while at $26^{\circ} \mathrm{C}$, more than $75 \%$ of hatching failure were observed. We thus consider that these conditions are out of the tolerance window of the species.

Detlaf et al. (1981, 1993) reported experimental evidences demonstrating that the best embryo survival in most Eurasian sturgeon species (no data about A. sturio) was $20{ }^{\circ} \mathrm{C}$. According to Wang et al. (1985), North American sturgeon species spawn in spring between 10 and $18{ }^{\circ} \mathrm{C}$. From thresholds described in Pörtner (2001; Pörtner and Farrell 2008; Clark et al. 2013), and on the basis of our behavioural test results, it can be concluded that the lower pejus temperature $\left(T_{p I}\right)$ for $A$. sturio embryo-larval phases can be estimated closer to 16 than $20^{\circ} \mathrm{C}$. On the basis of the larval tissue development index, the upper pejus temperature $\left(T_{p I I}\right)$ was estimated around $23{ }^{\circ} \mathrm{C}$. The high critical temperature $\left(T_{c I I}\right)$ can be estimated at between 26 and $30{ }^{\circ} \mathrm{C}$. Because of the range of temperatures tested, the low critical temperature $\left(T_{c I}\right)$ was not reached. As far as it can be concluded from the results of yolk sac resorption and chondrous development, the $T_{c I}$ can be estimated at around $12{ }^{\circ} \mathrm{C}$. These results suggest that European sturgeon early life phases are more tolerant than other Eurasian sturgeon species to high temperatures (Detlaf et al. 1993)

\section{Effects of hypoxia on European sturgeon embryos}

In the present study, the effects of hypoxia on embryos and larvae were clearly observed by a clear decrease in most of the criteria recorded. It is noteworthy that in our experiments below $50 \% \mathrm{O}_{2}$ sat, no hatching was observed whatever the temperature considered. Similar observations were reported in Acanthopagrus butcheri exposed during embryonic phase to $30 \% \mathrm{O}_{2}$ sat (Hassell et al. 2008b). This could be explained by the fact that oxygen demand during the embryonic phase is low (Gisbert et al. 2002) but very high for hatching. In our experiments, fish were able to withstand to hypoxia up to $70 \%$ $\mathrm{O}_{2}$ sat to ensure survival and routine metabolism. Low oxygen concentration impairs normal development, ultimately leading to mortality (Rombough 1988) and reduced hatching success (Hassell et al. 2008b). In this study, experimentation was carried but with hypoxia limited to the first $48 \mathrm{~h}$ of embryonic development. The results indicate that hypoxia has a delayed effect on hatching success. Indeed, individuals were exposed to hypoxia at early embryonic phase - the point at which development of all structures such as the cardio-vascular and respiratory systems takes place (Burggren and Pinder 1991). Hypoxia is known to impair such development (Shang and $\mathrm{Wu}$ 2004). Interestingly, in our results, suboptimal condition $\left(70 \% \mathrm{O}_{2}\right.$ sat) had no effect on tissue development and yolk sac resorption of sturgeon larvae. However, our behavioural results highlighted a significantly lower swimming speed at $70 \% \mathrm{O}_{2}$ sat and $20{ }^{\circ} \mathrm{C}$. Thus, we can suppose that a higher swimming speed is likely to be expressed in the best oxygen condition for an aerobic species.

\section{Combined effects of temperature and hypoxia on European sturgeon embryos}

Results obtained in this study point to the conclusion that the effects of oxygen depletion on European sturgeon embryo development and survival are more pronounced than those caused by variations in temperature except for tissue development and yolk sac resorption. According to Fry (1971), water temperature and dissolved oxygen availability are factors which limit the active metabolism, thus reducing routine metabolism when moving away from optimum conditions. The effects of hypoxia on aerobic metabolism at embryonic phase could explain the fact that the optimal temperature changes from $20{ }^{\circ} \mathrm{C}$ in normoxia to $16{ }^{\circ} \mathrm{C}$ in suboptimal condition. This variation could at least in part be attributed to the fact that $70 \% \mathrm{O}_{2}$ sat at $20{ }^{\circ} \mathrm{C}$ represents a lower oxygen concentration than the same oxygen saturation at $16{ }^{\circ} \mathrm{C}$. European sturgeon embryos exposed to suboptimal conditions $\left(70 \% \mathrm{O}_{2}\right.$ sat $)$ at low temperature $\left(\leq 16{ }^{\circ} \mathrm{C}\right)$ may not therefore have been suffering from a lack of oxygen. However, we cannot exclude delayed effects on European sturgeon. In zebrafish (Danio rerio) incubated at $28.5^{\circ} \mathrm{C}$ and exposed to hypoxia until $96 \mathrm{~h}$ post fertilisation 


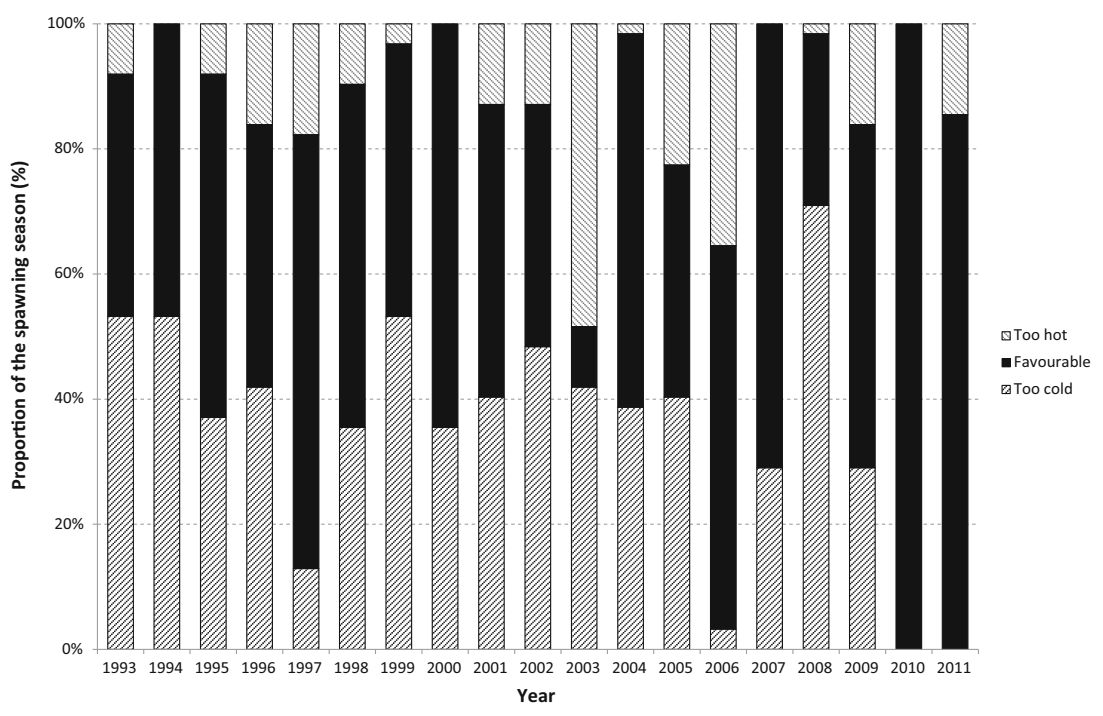

Fig. 8 Yearly favourable and unfavourable proportions of the breeding season (May-June). Daily mean temperature and O2 sat within the tolerance range (favourable), below (too cold) or above (too hot or not enough oxygen) for the European sturgeon. No data concerning oxygen were available for the 1993-2004 period. Temperature data were

(hpf), adaptation to metabolic stress induced a long-term decrease in heart rate (Shang and $\mathrm{Wu}$ 2004).

In the present study, we showed that occurrence of hypoxic events during early life phases, even on a short period of time, induced deleterious effects (survival and hatching success decrease,...) on developing sturgeons, and thus representing an important element in terms of conservation. The threshold of hypoxic effects can be estimated to be around $70 \% \mathrm{O}_{2}$ sat for European sturgeon embryos.

The optimal temperature for routine metabolism would appear to be $20{ }^{\circ} \mathrm{C}$ in normoxia as opposed to $16{ }^{\circ} \mathrm{C}$ in individuals exposed to $70 \% \mathrm{O}_{2}$ sat at early life phases in hypoxia. At $16{ }^{\circ} \mathrm{C}$, the metabolism of ectotherms decreases. Significant differences between the metabolic rate of individuals exposed to suboptimal condition and normoxia were observed only at $20{ }^{\circ} \mathrm{C}$ (from $25 \mathrm{mg} \mathrm{O} / / \mathrm{kg} / \mathrm{h}$ in hypoxic condition to $60 \mathrm{mg}$ $\mathrm{O}_{2} / \mathrm{kg} / \mathrm{h}$ in normoxic condition). At this temperature, the metabolism of individuals exposed to suboptimal condition was markedly lower than in normoxia suggesting the existence of an oxygen concentration threshold.

\section{Implications for European sturgeon embryonic development in the GGD basin}

As with most fish species, $A$. sturio's breeding period depends on temperature. Breeding occurs later in the northern than in the southern parts of the range (Magnin 1962). Observations performed in GGD basin show a mean surface water temperature close to $20{ }^{\circ} \mathrm{C}\left(\min =11.5{ }^{\circ} \mathrm{C}\right.$; $\left.\max =27.2{ }^{\circ} \mathrm{C}\right)$ and a mean oxygen saturation close to $90 \% \mathrm{O}_{2}$ sat $(\mathrm{min}=44.5 \%$ $\mathrm{O}_{2}$ sat; $\max =111.4 \% \mathrm{O}_{2}$ sat) during the natural breeding period (May-June) of this species (MAGEST 2011). According collected from MAGEST consortium (Portets and Libourne) and MIGADO association (Golfech and Tuilières) in four sites located downstream in Garonne and Dordogne rivers. Oxygen saturation data were from MAGEST consortium (Portets and Libourne) in two sites located downstream in the Garonne and Dordogne rivers

to the different thresholds obtained in this study, we counted the number of days with daily mean temperature and oxygen within the tolerance range of the species during the 2 months (May and June) of its breeding period (Fig. 8).

Every year within the 1993-2011 period (Fig. 8), we observed a favourable period in terms of temperature and oxygen levels measured in the Gironde-Garonne-Dordogne catchment during the European sturgeon's breeding period. However, the size of this favourable window between too cold and too hot temperatures is limited (median $55 \%$, min $10 \%$, $\max 100 \%$ ). These conclusions are consistent with those of Lassalle et al. (2010), who used large-scale analysis to evaluate the sustainability of the Garonne River until 2100. Actually, the low and high temperature conditions measured in 2003 led to the narrowest favourable window observed in the GGD during the analysed period for A. sturio embryonic development. The hypoxic events observed (2005 8 days, 200622 days and 20071 day) did not reduce the favourable temperature window as they correspond also to unfavourable temperature.

In the face of an imminent temperature rise due to global warming, there are two ways in which the reproduction process of European sturgeon may change. The first one is that the breeding period could occur earlier than reported for the previous periods similar to their southern breeding area (Magnin 1962). From the macroanalysis conducted with plant and animal data sets by Menzel et al. (2006), it appears that a phenological response would be as important as an advance of 15 days ( 2.5 days decade ${ }^{-1}$ ). According to a previous study (Delage et al. 2014), this hypothetical response would have a limited effect on the survival of this species in the GirondeGaronne-Dordogne basin, since juveniles are less sensitive 
than early life phases to temperature and oxygen variations. The other possibility is that the European sturgeon breeding period will remain unchanged. In this case, sturgeon early life phases would be subjected to higher temperatures and more intense or frequent hypoxic events than today. Development and hatching of young phases would be impacted, thus limiting recruitment and survival of the last remaining population of Acipenser sturio in the GGD basin. In both cases, global warming may have also indirect effects of sturgeons (availability of food, interaction with pollutants, maturation of adults).

In addition to distribution changes, biological interactions and their consequences at the ecosystem level remain a key question.

According to Lassalle et al. (2010), the current European sturgeon repartition area could shift North in order to find conditions more suitable to their survival.

Acknowledgements This study was carried out as part of the Cluster of Excellence COTE. Temperature and Oxygen data from the field were provided by the NGO Migrateurs Garonne Dordogne (MIGADO) (http://www.migado.fr/) and the consortium MAGEST. The English has been revised by James Emery. Thanks to David Mc Kenzie and Patrick Kestemont for reviewing a previous version of this text in the $\mathrm{PhD}$ manuscript of Nicolas Delage and two anonymous reviewers.

Funding information This study was funded by the Région Aquitaine, IRSTEA and the French National Research Agency (SturTOP research project No. ANR-13-CESA-0018-01).

Publisher's Note Springer Nature remains neutral with regard to jurisdictional claims in published maps and institutional affiliations.

\section{References}

Abe T, Sakamoto T (2011) Embryonic development and larval behavior of the kissing loach (Parabotia curta): adaptations to an ephemeral, hypoxic environment. Ichthyol Res 58:238-244

Acolas ML, Castelnaud G, Lepage M, Rochard E (2011) Chapter 10 biological cycle and migrations. In: Williot P, Rochard E, DesseBerset N, Kirschbaum F, Gessner J (eds) Biology and conservation of the Atlantic European sturgeon Acipenser sturio L., 1758. Springer, Berlin Heidelberg, pp 147-152

Burggren WW, Pinder AW (1991) Ontogeny of cardiovascular and respiratory physiology in lower vertebrates. Annu Rev Physiol 53:107135

Caballero Y, Voirin-Morel S, Habets F, Noilhan J, LeMoigne P, Lehenaff A, Boone A (2007) Hydrological sensitivity of the Adour-Garonne river basin to climate change. Water Resour Res 43:19

Claireaux G, Lefrançois C (2007) Linking environmental variability and fish performance: integration through the concept of scope for activity. Philos Trans R Soc Lond B Biol Sci 362:20312041

Clark TD, Sandblom E, Jutfelt F (2013) Aerobic scope measurements of fishes in an era of climate change: respirometry, relevance and recommendations. J Exp Biol 216:2771-2782

Dalla Via J, Van Den Thillart G, Cattani O, Cortesi P (1998) Behavioural responses and biochemical correlates in Solea solea to gradual hypoxic exposure. Can J Zool 76:2108-2113
Darias MJ, Lan Chow Wing O, Cahu C, Zambonino-Infante JL, Mazurais D (2010) Double staining protocol for developing European sea bass (Dicentrarchus labrax) larvae. J Appl Ichthyol 26:280-285

Delage N, Cachot J, Fraty R, Jatteau P (2014) Hypoxia tolerance of European sturgeon (Acipenser sturio L., 1758) young stages at two temperatures. J Appl Ichthyol 30:1195-1202

Detlaf TA, Ginzburg TA, Shmal'gauzen OI (1981) Development of sturgeon: egg maturation, fertilization, embryonic and prelarval development. Nauka Publishers, Moscow

Detlaf TA, Ginzburg AS, Shmal'gauzen OI (1993) Sturgeon fishes: developmental biology and aquaculture. Springer-Verlag, Berlin

Domenici P, Lefrançois C, Shingles A (2007) Hypoxia and the antipredator behaviours of fishes. Philos Trans R Soc Lond B Biol Sci 362: 2105-2121

Elliott JM, Elliott JA (2010) Temperature requirements of Atlantic salmon Salmo salar, brown trout Salmo trutta and Arctic charr Salvelinus alpinus: predicting the effects of climate change. J Fish Biol 77: 1793-1817

Elshout PMF, Dionisio Pires LM, Leuven RSEW, Wendelaar Bonga SE, Hendricks AJ (2013) Low oxygen tolerance of different life stages of temperate freshwater fish species. J Fish Biol 83:190-206

Fry FEJ (1971) Fish physiology. Academic press, New York

Gisbert E, Cech JJ Jr, Doroshov SI (2002) Routine metabolism of larval green sturgeon (Acipenser medirostris Ayres). Fish Physiol Biochem 25:195-200

Hassell KL, Coutin PC, Nugegoda D (2008a) Hypoxia impairs embryo development and survival in black bream (Acanthopagrus butcheri). Mar Pollut Bull 57:302-306

Hassell KL, Coutin PC, Nugegoda D (2008b) Hypoxia, low salinity and lowered temperature reduce embryo survival and hatch rates in black bream Acanthopagrus butcheri (Munro, 1949). J Fish Biol $72: 1623-1636$

IPCC (2013) Summary for policymakers. In Climate Change 2013: The Physical Science Basis. Contribution of Working Group I to the Fifth Assessment Report of the Intergovernmental Panel on Climate Change. Stocker TF, Qin D, Plattner G-K, Tignor M, Allen SK, Doschung J, Nauels A, Xia Y, Bex V, Midgley PM (eds). Cambridge University Press, pp. 3-29. https://doi.org/10. 1017/CBO9781107415324.004

Jego S, Gazeau C, Jatteau P, Elie P, Rochard E (2002) Les frayères potentielles de l'esturgeon européen Acipenser sturio L. 1758 dans le bassin Garonne-Dordogne. Méthodes d'investigation, état actuel et perspectives. Bull Fr Peche Piscic 365-366:487-505

Johnston IA, Lee HT, Macqueen DJ, Paranthaman K, Kawashima C, Anwar A, Kinghorn JR, Dalmay T (2009) Embryonic temperature affects muscle fibre recruitment in adult zebrafish: genome-wide changes in gene and microRNA expression associated with the transition from hyperplastic to hypertrophic growth phenotypes. J Exp Biol 212:1781-1793

Kappenman KM, Webb MAH, Greenwood M (2013) The effect of temperature on embryo survival and development in pallid sturgeon Scaphirhynchus albus (Forbes \& Richardson 1905) and shovelnose sturgeon S. platorynchus (Rafinesque, 1820). J Appl Ichthyol 29: 1193-1203

Kieffer JD, Baker DW, Wood AM, Papadopoulos CN (2011) The effects of temperature on the physiological response to low oxygen in Atlantic sturgeon. Fish Physiol Biochem 37:809-819

Killen SS, Marras S, Metcalfe NB, McKenzie DJ, Domenici P (2013) Environmental stressors alter relationships between physiology and behaviour. Trends Ecol Evol 28:651-658

Killen SS, Reid D, Marras S, Domenici P (2015) The interplay between aerobic metabolism and antipredator performance: vigilance is related to recovery rate after exercise. Front Physiol 6:111

Kovacs TG, Martel PH, Voss RH (2002) Assessing the biological status of fish in a river receiving pulp and paper mill effluents. Environ Pollut 118:123-140 
Lanoux A, Etcheber H, Schmidt S, Sottolichio A, Chabaud G, Richard M, Abril G (2013) Factors contributing to hypoxia in a highly turbid, macrotidal estuary (the Gironde, France). Environ Sci Processes Impacts 15:585-595

Larnier K, Roux H, Dartus D, Croze O (2010) Water temperature modeling in the Garonne River (France). Knowl Manag Aquat Ecosyst 398:20

Lassalle G, Crouzet P, Gessner J, Rochard E (2010) Global warming impacts and conservation responses for the critically endangered European Atlantic sturgeon. Biol Conserv 143:2441-2452

Lefrançois C, Domenici P (2006) Locomotor kinematics and behaviour in the escape response of European sea bass, Dicentrarchus labrax L., exposed to hypoxia. Mar Biol 149:969-977

Lepage, M. \& Rochard, E. (2011). Chapter 22 fishery by-catch of European sturgeon in the Bay of Biscay. In: Williot P, Rochard E, Desse-Berset N, Kirschbaum F, Gessner J (eds) Biology and conservation of the Atlantic European sturgeon Acipenser sturio L., 1758. Springer, Berlin Heidelberg, pp 335-342

Lo KH, Hui MNY, Yu RMK, Wu RSS, Cheng SH (2011) Hypoxia impairs primordial germ cell migration in zebrafish (Danio rerio) embryos. PLoS One 6:e24540

MAGEST (2011) http://www.magest.u-bordeaux1.fr

Magnin E (1962) Recherches sur la systématique et la biologie des Acipenséridés. Annales de la Station Centrale d'Hydrobiologie Appliquée 9:7-242

Menzel A, Sparks TH, Estrella N, Koch E, Aasa A, Ahas R, Alm-KÜBler K, Bissolli P, BraslavskÁ OG, Briede A, Chmielewski FM, Crepinsek Z, Curnel Y, Dahl Å, Defila C, Donnelly A, Filella Y, Jatczak K, Måge F, Mestre A, Nordli Ø, Peñuelas J, Pirinen P, RemiŠOvÁ V, Scheifinger H, Striz M, Susnik A, Van Vliet AJH, Wielgolaski F-E, Zach S, Zust ANA (2006) European phenological response to climate change matches the warming pattern. Glob Chang Biol 12:1969-1976

Mueller CA, Joss JMP, Seymour RS (2011) The energy cost of embryonic development in fishes and amphibians, with emphasis on new data from the Australian lungfish, Neoceratodus forsteri. J Comp Physiol B 181:43-52

Mustafa SA, Al-Subiai SN, Davies SJ, Jha AN (2011) Hypoxia-induced oxidative DNA damage links with higher level biological effects including specific growth rate in common carp, Cyprinus carpio L. Ecotoxicology 20:1455-1466

Nicholson G, Jenkins GP, Sherwood J, Longmore A (2008) Physical environmental conditions, spawning and early-life stages of an estuarine fish: climate change implications for recruitment in intermittently open estuaries. Mar Freshw Res 59:735-749

Pörtner H (2001) Climate change and temperature-dependent biogeography: oxygen limitation of thermal tolerance in animals. Naturwissenschaften 88:137-146

Pörtner HO, Farrell AP (2008) Physiology and climate change. Science 322:690-692
Rabalais NN, Díaz RJ, Levin LA, Turner RE, Gilbert D, Zhang J (2010) Dynamics and distribution of natural and human-caused hypoxia. Biogeosciences 7:585-619

Rochard E (2011) Chapter 18 present legal status of the European sturgeon Acipenser sturio. In: Williot P, Rochard E, Desse-Berset N, Kirschbaum F, Gessner J (eds) Biology and conservation of the Atlantic European sturgeon Acipenser sturio L., 1758. Springer, Berlin Heidelberg, pp 251-256

Rochard E, Castelnaud G, Lepage M (1990) Sturgeons (Pisces: Acipenseridae); threats and prospects. J Fish Biol 37:123-132

Rochard E, Lepage M, Meauze L (1997) Identification et caractérisation de l'aire de répartition marine de l'esturgeon européen Acipenser sturio à partir de déclarations de captures. Aquat Living Resour 10:101-109

Rochard E, Lepage M, Dumont P, Tremblay S, Gazeau C (2001) Downstream migration of juvenile European sturgeon Acipenser sturio L. in the Gironde estuary. Estuaries 24:108-115

Rombough PJ (1988) 2 Respiratory gas exchange, aerobic metabolism, and effects of hypoxia during early life. Fish Physiol 11:59-161

Rosenthal H, Bronzi P, Gessner J, Moreau D, Rochard E, Lasen C (2007) Draft action plan for the conservation and restoration of the European sturgeon (Acipenser sturio). Council of Europe, Convention on the conservation of European wildlife and natural habitats, Strasbourg, p 47

Shang EHH, Wu RSS (2004) Aquatic hypoxia is a teratogen and affects fish embryonic development. Environ Sci Technol 38:4763-4767

Shields RJ, Brown NP, Bromage NR (1997) Blastomere morphology as a predictive measure of fish egg viability. Aquaculture 155:1-12

Spitsbergen JM, Tsai HW, Reddy A, Miller T, Arbogast D, Hendricks JD, Bailey GS (2000) Neoplasia in zebrafish (Danio rerio) treated with 7,12-dimethylbenz[a]anthracene by two exposure routes at different developmental stages. Toxicol Pathol 28:705-715

Wang YL, Binkowski FP, Doroshov SI (1985) Effect of temperature on early development of white and lake sturgeon, Acipenser transmontanus and A. fulvescens. Environmental Biology of Fishes 14:43-50

Williot P, Castelnaud G (2011) Chapter 20 historic overview of the European sturgeon Acipenser sturio in France: surveys, regulations, reasons for the decline, conservation, and analysis. In: Williot $\mathrm{P}$, Rochard E, Desse-Berset N, Kirschbaum F, Gessner J (eds) Biology and conservation of the Atlantic European sturgeon Acipenser sturio L., 1758. Springer, Berlin Heidelberg, pp. 285-308

Williot P, Rochard E, Desse-Berset N, Gessner J, Kirschbaum F (2011) Chapter 1 brief introduction to sturgeon with a special focus on the European sturgeon, Acipenser sturio L. 1758. In: Williot P, Rochard E, Desse-Berset N, Kirschbaum F, Gessner J (eds) Biology and conservation of the Atlantic European sturgeon Acipenser sturio L., 1758. Springer, Berlin Heidelberg, pp 3-12 